\title{
Fighting the tragedy of nursing homes in the COVID-19 pandemic
}

\author{
Máximo Bernabeu-Wittel, ${ }^{1,2 *}$, Lourdes Moreno-Gaviño ${ }^{1}$, Dolores Nieto-Martín ${ }^{1}$, Concepción Conde-

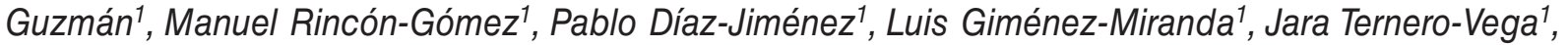 \\ Sonia Gutiérrez-Rivero ${ }^{1}$, Ignacio Vallejo-Maroto ${ }^{1}$, Reyes Aparicio-Santos ${ }^{1}$, Carlos Jiménez-Juan ${ }^{1}$, and \\ Manuel Ollero-Baturone ${ }^{1}$ \\ ${ }^{1}$ Department of Internal Medicine, Hospital Universitario Virgen del Rocío; ${ }^{2}$ Department of Medicine, Universidad de Sevilla. Sevilla, Spain
}

\begin{abstract}
During the last months, the pandemic caused by the severe acute respiratory syndrome coronavirus 2 (SARS-CoV-2) has hit cruelly elderly citizens living in nursing homes (NHs) across the world. As a matter of fact, $\mathrm{NHs}$ are highly vulnerable to the occurrence of this new coronavirus disease (COVID-19), which results in high lethality rates. In addition, most of the long-term care facilities are not yet prepared to manage with this new epidemiological and clinical scenario. In this article, we will review the impact of COVID-19 in NH, its causes and underlying factors, and the possible solutions of keeping SARS-CoV-2 at bay in $\mathrm{NH}$ from a triple perspective: the focus of public health policies and global measures, the operative level at $\mathrm{NH}$ institutions themselves, and the daily clinical scenario of clinicians and other health care workers.
\end{abstract}

Key words: Coronavirus disease-19. Severe acute respiratory syndrome coronavirus 2. Community-based long-term care. Frailty. Multimorbidity. Nursing homes.

\section{Introduction}

The pandemic caused by the severe acute respiratory syndrome coronavirus 2 (SARS-CoV-2) is beating most countries in the world, with nearly 160 million of cases, and more than $3,290,000$ deaths reported as of May $12,2021^{1}$. The disease affects more frequently and severely elderly citizens; in fact, they make up around $30 \%$ of all cases, $45-50 \%$ of all hospitalizations, and $80 \%$ of all deaths ${ }^{2,3}$. In these age strata, SARS-CoV-2 disease (coronavirus disease [COVID19]) lethality rate can reach up to $20-40 \%{ }^{4}$. In virtually all countries, we have painfully experienced, that one of the most helpless environments for the expansion of SARS-CoV-2 are nursing homes (NHs) ${ }^{5,6}$. In these facilities, the impact of COVID-19 is a real danger that can be devastating 6,7 .

In this article, we will review the impact of COVID-19 in $\mathrm{NH}$, its causes and underlying factors, and the possible solutions for keeping SARS-CoV-2 at bay in $\mathrm{NH}$ from a triple perspective: public health, $\mathrm{NH}$ institutions themselves, and health care workers.

\section{Impact of COVID-19 in NHs}

Already from at the beginning of the pandemic, $\mathrm{NH}$ suffered from outbreaks of the disease. These outbreaks were always characterized by a "silent" entry of

\section{Visual abstract available at https://spanishjmed.com/frame_esp.php?id=50}

\section{Correspondence:}

*Máximo Bernabeu-Wittel

E-mail: wittel@cica.es

2696-5631 / @ 2021 Sociedad Española de Medicina Interna. Published by Permanyer. This is an open access article under the CC BY-NC-ND license (http://creativecommons.org/licenses/by-nc-nd/4.0/).
Date of reception: 03-02-2021

Date of acceptance: $20-05-2021$

DOI: $10.24875 /$ SJMED.21000004
Available online: 05-10-2021 Span J Med. 2021;1(3):154-161

www.spanishjmed.com 
SARS-CoV-2 and a subsequent "explosion" of cases among both, residents and care professionals, affecting up to $60 \%$ and $30 \%$ of them, respectively ${ }^{5}$. More than 400 papers have been already published regarding COVID-19 in NH. The first well-documented outbreaks were described and analyzed in Singapore and the United States of America ${ }^{7-9}$. In all these early reports, the authors found high attack rates on residents and workers, with hospitalization and mortality rates over $50 \%$ and $30 \%$ of affected residents, respectively ${ }^{7-9}$. These experiences brought up the potential deleterious impact of COVID-19 in NH (and subsequently in local health-care systems) and suggested the fact that once SARS-CoV-2 enters into a long-term care facility, it has the potential to spread rapidly and widely. The main routes of entry of the virus into $\mathrm{NH}$ were visitors and workers. This fact underscores the importance of proactive actions to identify and exclude potentially infected staff and visitors, as well as early recognition of potentially infected patients, and implementation of appropriate infection prevention and control measure ${ }^{5-9}$.

As SARS-CoV-2 progressively increased its incidence in the community, it was paralleled by more and more outbreaks in an increasing number of $\mathrm{NH}$, until they became one of the hottest spots in the current pandemic ${ }^{9-11}$. This tragedy wave occurred in most world countries, with special virulence in those with more aged populations and a higher density of long-term care facilities. As a matter of fact, in the United States of America, it is calculated that more than $2300 \mathrm{NH}$ had been affected until April $2020^{12}$. Another specially hit country is Spain, in which more than 20,000 citizens living in $\mathrm{NH}$ are estimated to have died during the first wave of COVID-19 pandemic ${ }^{6,13}$.

In the last months, many clinicians and professional institutions have been warning society and authorities of the need to pay more attention and dedicate more resources to preventing and combating COVID-19 in long-term care facilities ${ }^{14-17}$. These recommendations had a heterogeneous influence among countries, but at less have contributed to highlight the vulnerability of these citizens toward this new disease, which has conditioned, that in many places, they are the priority population for starting vaccination programs ${ }^{18,19}$. The effectiveness of vaccination in these vulnerable populations has already been demonstrated; as of today, outbreaks in $\mathrm{NH}$ have virtually disappeared and the incidence and mortality of COVID-19 in citizens over 80 years of age has decreased drastically in Spain ${ }^{19}$.

\section{Causes and underlying conditions of the "perfect storm"}

Three major features converging in $\mathrm{NH}$ can explain this experienced "perfect storm:" First, the characteristics of the resident population, second, the structural and professional peculiarities of the residential care model, and at last, the global tension and saturation of the health and social care systems at the peak of the pandemic.

The residents of $\mathrm{NH}$ are characterized by their old age, the presence of multiple and severe chronic diseases (such as advanced dementia, chronic heart failure, and others), a high burden of comorbidities, and elevated dependence rates. In these age strata, COVID-19 lethality rate can reach up to $50 \%{ }^{2,3}$. This increased mortality may be explained in part by already known risk factors (frailty, infection acting as a trigger to decompensate other chronic conditions, immunosenescence, and development of geriatric syndromes' cascade). In fact, the impact of comorbidities in the outcome of multiple acute diseases has largely been demonstrated, and in a recent large multicenter cohort of patients with COVID-19, chronic cardiac disease, non-asthmatic chronic pulmonary disease, chronic kidney disease, liver disease, and obesity were associated with higher in-hospital mortality ${ }^{20}$. In addition, death-risk scores assessing multimorbidity issues like PROFUND index have proven their usefulness in the survival prediction of $\mathrm{NH}$ residents with COVID-1921.

$\mathrm{NHs}$, like other closed or half-closed institutions, are predisposed to epidemic outbreaks of airborne or contact pathogens as already widely documented ${ }^{22,23}$. The high dependence levels of residents for basic activities of daily living (such as bathing, dressing, feeding, or transfers) increase the likelihood of transmission through the care staff. But beyond these factors, SARS-CoV-2 pandemic has highlighted the main weaknesses of the social care systems. In many countries, $\mathrm{NHs}$ are located in the border of health-care and social services, and because of that, their connections and boundaries to both systems are somehow imprecise ${ }^{5,6}$. There are regulatory failures leading to lack of delimitation of responsibilities; funding shortfalls leading to structural problems and suboptimal staff training; a market-oriented model without strict quality control measures; and heterogeneous support from the health-care system, which frequently delegates its tasks to the $\mathrm{NH}$ teams themselves ${ }^{24,25}$. Under these circumstances, $\mathrm{NH}$ faced the pandemic lacking infrastructures and work flows to manage an epidemic of this magnitude; many of them were poorly connected with the health-care system; counted with lower staff ratio (usually planned to attend 
Table 1. Public health measures carried out or proposed by different countries and institutions to prevent SARS-CoV-2 from entering $\mathrm{NH}$

Public health measures

Global, coordinated, coherent, and transparent plans for the management of COVID-19 in NH

Strengthen the integration of $\mathrm{NH}$ with the health-care system

Provide clinical teams (combining professionals from primary and hospital care) to attend possible outbreaks in NH

Prepare for separation of clean and contaminated spaces, circuits, professionals, and shifts in case of outbreaks, in $\mathrm{NH}$

Provide evacuation centers (campaign hospitals, medicalized hotels...) for outbreaks in NH with unavailability of separation measures

Specific training programs to workers and managers of $\mathrm{NH}$

Limit/ban any visit and entry to NH (family members, volunteers, providers...) when high community incidence rates

Strict control on health status and SARS-CoV-2 exposure of NH staff members

Reinforcement/increase of NH staff to face higher workload, and possible decrease of personnel due to exposure to SARS-CoV-2

Extreme prevention measures in the daily care of residents with a higher level of dependency

Ensure support for and availability of adequate personal protective equipment

Avoid unnecessary trips and outings. Promotion of telemedicine and e-health devices for medical revisions

Regular viral testing of $\mathrm{NH}$ staff and residents

Ongoing screening of all individuals who are admitted to NH

Isolate or quarantine all admissions from hospitals or other high-risk areas, regardless of test results

Massive vaccination of all NH residents

\section{Field of action}

Full society

Social and health care systems

Health-care system

Social care system

Social and health-care systems

Social Care System

Full society

NH staff

NH staff

NH staff

NH staff

NH population

NH staff and residents

$\mathrm{NH}$ residents

$\mathrm{NH}$ residents

Health-care system

NH: nursing home.

"stable" residents); and had suboptimal staff training and expertise in managing patients with COVID-19. The time has come to rethink the role and place of $\mathrm{NH}$ in our societies on a global scale, and to work on a deeper integration of health and social care.

At last, the saturation of health care systems during the peak of the pandemic nearly reached the collapse, leading to an extreme lack of material and professionals in hospitals and primary care. All countries and citizens were aware of these disaster situations, which involved ethical issues, prioritizing measures, as well as resources allocation and reallocation to save most lives, and lives of severely ill patients with highest survival probability ${ }^{26-30}$.

\section{A global strategy is needed to fight the storm. Political measures and public health}

The responses of country federations and the countries themselves to this new virus challenge have been heterogeneous. Countries articulating an early response, with more restrictive measures in terms of stopping the main routes of transmission, and more coherent, homogeneous and clear guidelines, developing actions in the main "hot spots," have obtained better results in terms of SARS-CoV-2 spread, morbidity, and mortality. In contrast, in countries that decided more permissive measures to generate herd immunity or to safeguard the economy, the impact of the epidemic has been much more devastating ${ }^{31}$. This proofs the importance of global political measures, which should always be guided by scientific knowledge. In this extraordinary situation, governments and institutions have to make difficult and complex decisions, but the ultimate goal should be to save as many lives as possible, even if many elements of our daily lives have to be given up.

Dealing with the tragedy of $\mathrm{NH}$ requires a coordinated response from society as a whole. National, regional, 
Table 2. Different approaches to manage with COVID-19 outbreaks in nursing homes

\begin{tabular}{|c|c|c|c|}
\hline Approach & Advantages & Disadvantages & Best use \\
\hline $\begin{array}{l}\text { On-site } \\
\text { medicalization }\end{array}$ & $\begin{array}{l}\text { - Efficacious } \\
\text { - Reduces mortality and hospital referrals } \\
\text { - Offers optimal palliative care to those } \\
\text { residents in their end-of-life periods } \\
\text { - Maintains preserves home feeling and usual } \\
\text { caregivers }\end{array}$ & $\begin{array}{l}\text { - Needs substantial number of } \\
\text { health-care professionals and } \\
\text { equipment }\end{array}$ & $\begin{array}{l}\text { - Large sized NH } \\
\text { - Large outbreaks } \\
\text { - Palliative care NH }\end{array}$ \\
\hline $\begin{array}{l}\text { Evacuation of } \\
\text { infected residents* }\end{array}$ & - Easy and fast & $\begin{array}{l}\text { - Needs facilities reconditioning } \\
\text { - Disconnection from home and } \\
\text { usual caregivers } \\
\text { - Potential stay of asymptomatic } \\
\text { infected residents }\end{array}$ & $\begin{array}{l}\text { - Medium-sized NH } \\
\text { - Small outbreaks }\end{array}$ \\
\hline $\begin{array}{l}\text { Evacuation of } \\
\text { non-infected } \\
\text { residents }\end{array}$ & - Easy and fast & $\begin{array}{l}\text { - Needs facilities reconditioning } \\
\text { - Disconnection from home and } \\
\text { usual caregivers } \\
\text { - Potential evacuation of } \\
\text { asymptomatic infected residents }\end{array}$ & $\begin{array}{l}\text { - Medium-sized NH } \\
\text { - Small outbreaks }\end{array}$ \\
\hline $\begin{array}{l}\text { Evacuation of all } \\
\text { residents* }\end{array}$ & $\begin{array}{l}\text { - Easy and fast } \\
\text { - Allows an early NH disinfection }\end{array}$ & $\begin{array}{l}\text { - Needs facilities reconditioning } \\
\text { - Disconnection from home and } \\
\text { usual caregivers } \\
\text { - Potential transmission to other } \\
\text { hosts beyond the } \mathrm{NH}\end{array}$ & $\begin{array}{l}\text { - Small-sized NH } \\
\text { - Small outbreaks }\end{array}$ \\
\hline
\end{tabular}

${ }^{*}$ To medicalized facilities such as hotels, hospitals, or campaign hospitals. NH: nursing home.

and local governments need to develop a coherent and coordinated plan, devoting all necessary resources to preserving the health of $\mathrm{NH}$ residents. All public institutions, scientists, and the media must raise awareness among the public at large to avoid unnecessary exposure of the most frail populations to SARS-CoV-2. Finally at individual levels, the recommendations of the experts must be accomplished, and the authorities have to prioritize the enough resources to deal with COVID19 in $\mathrm{NH}$.

Focusing on specific public health measures, there are some which have been performed and/or proposed by some countries and institutions, as detailed in table 15-7,14-17,25,31-35. These actions are oriented to three levels: to the political institutions and society as a whole to make the vulnerability of $\mathrm{NH}$ visible and to raise awareness among the entire population of the importance of devoting resources to these institutions; to the social and health systems to improve their coordination, teamwork, and cooperation actions; and finally, to workers and residents of $\mathrm{NH}$ to ensure the necessary structural changes in the centers, the professional skills in the prevention and management of COVID-19, the necessary equipment and protection measures, and the universal and regular screening of workers and residents.

\section{Keeping at bay SARS-CoV-2}

in the operative level. A pragmatic approach to manage $\mathrm{NH}$ outbreaks

The management of $\mathrm{NH}$ outbreaks has been also different during the pandemic. Most frequent approaches are detailed in table 2. In the last months, we have accumulated experience in the on-site medicalization programs in our area and will detail the main actions to develop such programs.

In the medicalization program of a $\mathrm{NH}$ with a COVID19 outbreak, it is crucial to establish a relationship of trust among NH staff and health-care staff to carry out an optimal teamwork. When first facing with an outbreak, there are a lot of tasks to arrange, so it is useful to follow a checklist of priority actions. These can be summarized in nine:

1. Visiting the $\mathrm{NH}$ to identify the responsible person, evaluate needs, establish immediate measures, and plan the following, clearly assigning roles and responsibilities.

2. Evaluating material resources, equipment, expendables, and medication needs (informatics, a portable ultrasound device, oxygen therapy, material for blood extractions, intravenous and subcutaneous lines, intravenous fluids, intravenous drugs...); and providing the necessary. 
3. Identifying the needs of health care workers (physicians and nurses). Mobilizing the coordinated team (primary care and hospital professionals) to provide clinical attention $24 \mathrm{~h}$ during 7 days in the week.

4. Locating a "clean room" for informatics equipment, clinical work, consulting and writing in electronic clinical charts, and administrative tasks. Establishing full connection with health-care electronic information systems.

5. Locating a secure locker room for $\mathrm{NH}$ staff and health care workers' dressing and undressing. Ensuring enough PPE supplies to all team members.

6. Universal SARS-CoV-2 testing to residents and staff members to detect active infections, by performing real-time polymerase chain reaction (RTPCR) for the detection of specific viral ribonucleic acid (RNA) from nasopharyngeal swab smears. Repeating test after 7 days, or if symptoms development to not infected residents. Performing a meticulous epidemiological survey and follow-up to trace the outbreaks' origin and evolution.

7. Establishing a "clean area" with rooms and common spaces for uninfected residents, and a "contaminated area" with rooms and common spaces for residents with confirmed infection. Warranting the compulsory use of PPE to all members of the work team while remaining in the contaminated area.

8. Specific training of staff members in the management and care of COVID-19 patients. Separation of those working in the clean area and those working in the contaminated area, with prohibition to change shifts between professionals from these two areas. Proper clinical attention and quarantine of staff members with confirmed SARS-CoV-2 acute infection.

9. Ensuring common clinical management, and communication protocol to inform residents' families.

It may be practical to count with a "survival kit" of expendables and medications, to manage COVID19 patients the first 48-72 h, until the supply circuit is operational. We detail this kit in table 3.

After controlling the outbreak, it is important to establish a demedicalization process. We consider that after 14 days of the last confirmed COVID-19 case, the $\mathrm{NH}$ is eligible for demedicalization. In this process, the following five requirements should be ensured: (1) A contingency plan with infection and prevention measures, active surveillance, actions in case of new infections, and provision of spaces and rooms for possible future "contaminated areas." (2) Urgent notification of the appearance of suspected cases compatible with
Table 3. "Survival kit" for the initial approach of COVID-19 outbreaks in nursing homes

\begin{tabular}{|c|c|}
\hline "Survival kit"* & Number \\
\hline $\begin{array}{l}\text { Health care clothing } \\
\text { - Personal protective equipment } \\
\text { - Gloves, surgical caps, and shoe } \\
\text { covers (different sizes) } \\
\text { - FFP2 and surgical masks } \\
\text { - Surgical gowns } \\
\text { - Hydroalcoholic gel } \\
\text { - Protection glasses }\end{array}$ & $\begin{array}{c}20 \\
100,100,100 \\
50,50 \\
20 \\
1000 \mathrm{~mL} \\
5\end{array}$ \\
\hline $\begin{array}{l}\text { Medical devices } \\
\text { - Oxygen nasal cannulas and } \\
\text { different concentration masks } \\
\text { - Portable oxygen concentrators } \\
\text { - Portable ultrasound dispositive }\end{array}$ & $\begin{array}{c}10,10 \\
3 \\
1\end{array}$ \\
\hline $\begin{array}{l}\text { Intravenous fluids and associated } \\
\text { material } \\
\text { - Needles (subcutaneous, } \\
\text { intramuscular, intravenous, and } \\
\text { trocar) } \\
\text { - Syringes (2 mL, } 5 \mathrm{~mL} \text {, and } 10 \mathrm{~mL} \text { ) } \\
\text { - Intravenous lines } \\
\text { - Subcutaneous lines } \\
\text { - Dosimeters (Dosiflow }{ }^{\circledR} \text { ) } \\
\text { - Infusers } \\
\text { - Peripheral catheters (Abocath } \\
20 \text { and Abocath } \\
\text { } 22 \text { ) } \\
\text { - Dressings and adhesive tapes } \\
\text { - Chlorhexidine, } 70^{\circ} \text { ethanol, or } \\
\text { povidone iodine } \\
\text { - Saline } 1000,250, \text { and } 100 \mathrm{~mL} \\
\text { - Glucose } 5 \% 500 \mathrm{~mL} \\
\text { - Glucosaline } 500 \mathrm{~mL}\end{array}$ & $\begin{array}{c}20,20,20 \\
20 \\
10 \\
10 \\
3 \\
15,15 \\
\\
30 \\
1000 \mathrm{~mL} \\
5,5,5 \\
3 \\
3\end{array}$ \\
\hline $\begin{array}{l}\text { Medications } \\
\text { COVID-19 supplies } \\
\text { - Dexamethasone } 4 \mathrm{mg} \text { (iv) } \\
\text { - Methyl-prednisolone } 40 \mathrm{mg} \text { (iv) } \\
\text { - Furosemide } 20 \mathrm{mg} \text { (iv) } \\
\text { - Metoclopramide } 10 \mathrm{mg} \text { (iv/sc) } \\
\text { - Enoxaparin } 20,40,60 \mathrm{mg} \text { (sc) } \\
\text { - Remdesivir } \\
\text { - Tocilizumab }\end{array}$ & $\begin{array}{c}50 \\
500 \\
100 \\
500 \\
50,100,50 \\
\text { On request } \\
\text { On request }\end{array}$ \\
\hline $\begin{array}{l}\text { Anti-bacterial supplies } \\
\text { - Ceftriaxone } 2 \mathrm{~g} \text { (iv) } \\
\text { - Ceftriaxone } 1 \mathrm{~g} \text { (im) } \\
\text { - Levofloxacin } 500 \mathrm{mg} \text { (iv) } \\
\text { - Levofloxacin } 500 \mathrm{mg} \text { (tablets) }\end{array}$ & $\begin{array}{l}75 \\
30 \\
75 \\
30\end{array}$ \\
\hline $\begin{array}{l}\text { Respiratory supplies } \\
\text { - Salbutamol (inhaler) } \\
\text { - Ipratropium (inhaler) } \\
\text { - Formoterol/budesonide (inhaler) } \\
\text { - Inhalation chambers }\end{array}$ & $\begin{array}{l}50 \\
50 \\
25 \\
25\end{array}$ \\
\hline $\begin{array}{l}\text { Other medications } \\
\text { - Acetaminophen } 1 \mathrm{~g} \text { (iv) } \\
\text { - Acetaminophen } 500 \mathrm{mg} \text { (tablets) } \\
\text { - Morphine } 10 \mathrm{mg} \mathrm{(iv/sc)} \\
\text { - Midazolam } 15 \mathrm{mg}, 50 \mathrm{mg} \text { (iv/sc) } \\
\text { - Levomepromazine } 25 \mathrm{mg} \text { (iv/sc) } \\
\text { - Haloperidol } 5 \mathrm{mg} \text { (iv/sc) } \\
\text { - Scopolamine } 0.5 \mathrm{mg} \text { (iv/sc) }\end{array}$ & $\begin{array}{l}500 \\
200 \\
500 \\
100,50 \\
20 \\
50 \\
200\end{array}$ \\
\hline
\end{tabular}

*This "kit" is planned to cover the first 24-48 h of on-site medicalization of NH with COVID-19 outbreaks affecting initially 40-50 residents. 
Table 4. Proposed death risk stratification approach in elderly patients living in nursing homes

\begin{tabular}{|l|l|}
\hline Index score & Proposed approach \\
\hline PROFUND $\downarrow$ and CURB-65 $\downarrow$ & $\begin{array}{l}\text { - Etiologic-pathogenic approach } \\
\text { - Standard care* }\end{array}$ \\
\hline PROFUND $\downarrow$ and CURB-65 $\uparrow$ & $\begin{array}{l}\text { - Etiologic-pathogenic approach } \\
- \text { Intensified care\# }\end{array}$ \\
\hline PROFUND $\uparrow$ and CURB-65 $\downarrow$ & $\begin{array}{l}\text { - Symptomatic approach } \\
\text { - Standard care* }\end{array}$ \\
\hline PROFUND $\uparrow$ and CURB-65 $\uparrow$ & - Symptomatic approach \\
\hline
\end{tabular}

*Standard ward or nursing home; \# including transfer to intensive care unit; $\&$ including the offer of palliation, palliative sedation, and spiritual care.

COVID-19. (3) Continuous training to staff members. (4). Staff members control through daily temperature measurement and a responsible declaration at the entrance to the workplace of not having symptoms compatible with COVID-19, and in case of symptoms onset, urgent notification. (5) Public and auditable weekly checklist of the infection control measures ${ }^{5}$.

\section{Managing and treating old frail patients with COVID-19. The daily clinical trench}

Managing elderly frail patients with COVID-19 are a triple challenge.

First, their symptoms are more vague, unspecific, and similar to other acute conditions (many of them develop only geriatric syndromes such as delirium, falls, or neuromuscular dysphagia) $)^{36,37}$. Other typical COVID-19 symptoms such as fever, odynophagia, anosmia, or ageusia are also uncommon. Hence, a high suspicion level is needed to early recognize, confirm, isolate incidental cases, and avoid further transmission in $\mathrm{NH}$.

Second, many of these patients suffer comorbidities or are indeed polypathological patients, whose conditions frequently get decompensated and need to be globally treated. It is common that these patients develop heart failure, bronchial hyperreactivity, and a variety of geriatric syndromes (immobilization, constipation, acute urinary retention, and among others), which need specific expertise in their integral management.

And third, a deep knowledge of multimorbidity, frailty, and geriatric medicine is needed to establish best clinical actions and treatments. An earlier symptoms recognition by well-trained professionals is needed to lead to earlier treatment and support measures; in this sense, treating very old patients with potentially acceptable life expectancy is safe and of benefit; otherwise, we could fall in a somehow nihilist deviation of clinical practice. Besides, a gentle attention to the most frail and terminally ill residents will enable a personalized care according to preferences of patients and families; the rush of a pandemic situation should not make palliative care invisible, on the contrary, an optimal palliative care has to be offered to this selected population to avoid futility and unnecessary iatrogenia ${ }^{38}$.

Among the multiple COVID-19 prognostic scores, the presence of multimorbidity, chronic conditions, and functional status is often forgotten. However, in this population, chronic conditions are of similar relevance of severity of COVID-19 in determining patient's survival. This fact has been demonstrated also in many other acute and chronic diseases ${ }^{39-41}$. Hence, we propose the death risk stratification to be performed on two axis detailed in table $4^{21}$. The first dimension to assess should be the death risk due to basal status and severity of chronic conditions, by means of a co-morbidity tool like PROFUND index ${ }^{42}$; with this assessment, we could differentiate those patients with good life expectancy in which a nihilist practice should be avoided and an etiologic-pathogenic approach is the best choice; and those patients with basal severe illnesses or already in their end-of-life trajectory, in which futility and iatrogenia should be avoided and a more symptomatic approach is the best clinical practice. The second axis is the current death risk due to the severity of COVID-19, by means of a pneumonia severity tool like CURB-65 index ${ }^{43}$; standard care should be offered to patients with mild-moderate disease, while an intensified care with advanced measures (intensive care for those with good life expectancy and advanced palliative care for those who are already in their end-of-life process) is the best option for those with severe COVID-1921.

At last, it may be useful to prepare a checklist of important issues to consider and consign in the daily clinical evaluation and care of all patients (such as clinical status, vital signs, global approach, treatments, patient and family preferences...). This checklist should be available to all members of the work team.

\section{Conclusions}

$\mathrm{NHs}$ are highly vulnerable to the occurrence of COVID-19 outbreaks, which are unfortunately burdened with high mortality rates among residents.

Three converging features can explain this "perfect storm:" The characteristics of the resident population, the structural and professional singularities of the residential care model, and the global tension and 
saturation of the health and social care systems during pandemic peaks.

Dealing with the tragedy of $\mathrm{NH}$ requires a coordinated response from national, regional, local governments, and societies as a whole. Best results in terms of stopping transmission have been obtained with an early response, restrictive measures, and with coherent, homogeneous and clear guidelines, developing actions in the main "hot spots."

It is important to carefully plan the management of COVID-19 outbreaks in NH. The best choice will depend on the $\mathrm{NH}$ and outbreak size. Possible solutions are on-site medicalization programs or partial/total evacuation to other appropriate facilities.

Finally, an optimal clinical attention of these patients is of vital importance. They frequently develop non-specific symptoms as well as geriatric syndromes as manifestations of COVID-19, and their comorbidities often get decompensated. In their clinical approach, an exquisite prognostic stratification may be of considerable help.

\section{Funding}

This research did not receive any specific grant from funding agencies in the public, commercial, or not-for profit sectors.

\section{Conflicts of interest}

The authors declare that they have no conflicts of interest.

\section{Ethical disclosures}

Protection of human and animal subjects. The authors declare that no experiments were performed on humans or animals for this study.

Confidentiality of data. The authors declare that no patient data appear in this article.

Right to privacy and informed consent. The authors declare that no patient data appear in this article.

\section{Acknowledgments}

Members of the RESICOVID Study Group are detailed below:

Reyes Aparicio-Santos ${ }^{1}$, Máximo Bernabeu-Wittele1,2, Silvia Calzón-Fernández ${ }^{3}$, Concepción Conde-Guzmán', Juan Delgado de la Cuesta', Pablo Díaz-Jiménez ${ }^{1}$, Luis Giménez-Miranda ${ }^{1}$, Sonia Gutiérrez-Rivero ${ }^{1}$, Carlos
Jiménez-Juan ${ }^{1}$, Lourdes Moreno-Gaviño', Mํㅡ Mar Muñoz-García ${ }^{4}$, Dolores Nieto-Martín ${ }^{1}$, Manuel OlleroBaturone ${ }^{1}$, Manuel Rincón-Gómez ${ }^{1}$, Jara Ternero-Vega ${ }^{1}$, Ignacio Vallejo-Maroto ${ }^{1}$

${ }^{1}$ Internal Medicine Department, Hospital Universitario Virgen del Rocío; ${ }^{2}$ Medicine Department, Universidad de Sevilla; ${ }^{3}$ Centro de la Salud de Atención Primaria Los Bermejales, Distrito de Atención Primaria; ${ }^{4}$ Epidemiology and Public Health Department, Distrito de Atención Primaria. Seville, Spain

\section{References}

1. European Centre for Disease Control and Prevention. COVID-19 Situation Update Worldwide, as of Week 18; 2021. Available from: https://www. ecdc.europa.eu/en/geographical-distribution-2019-ncov-cases. [Last accessed on 2021 May 16].

2. Zhou F, Yu T, Du R, Fan G, Liu Y, Liu Z, et al. Clinical course and risk factors for mortality of adult inpatients with COVID-19 in Wuhan, China: a retrospective cohort study. Lancet. 2020;395:1054-62.

3. Casas-Rojo JM, Antón-Santos JM, Millán-Núñez-Cortés J, Lumbreras-Bermejo C, Ramos-Rincón JM, Roy-Vallejo E, et al. on behalf of SEMI-COVID-19 network. Clinical characteristics of patients hospitalized with COVID-19 in Spain: results from the SEMI-COVID-19 registry. Rev Clin Esp. 2020;220:480-94.

4. Ramos-Rincon JM, Buonaiuto V, Ricci M, Martín-Carmona J, Paredes-Ruíz D, Calderón-Moreno M, et al, SEMI-COVID-19 Network. Clinical characteristics and risk factors for mortality in very old patients hospitalized with COVID-19 in Spain. J Gerontol A Biol Sci Med Sci. 2021;76:e28-37.

5. Bernabeu-Wittel M, Ternero-Vega JE, Nieto-Martín MD, Moreno-Gaviño L, Conde-Guzmán C, Delgado-Cuesta J, et al. Effectiveness of a on-site medicalization program for nursing homes with $\mathrm{CO}$ VID-19 outbreaks. J Gerontol A Biol Sci Med Sci. 2021;76:e19-27.

6. Bernabeu-Wittel M, Gómez-Huelgas R, Nieto-Martín MD, SEMI-COVID-19 Network. Time to stop the tragedy in Spanish nursing homes during the COVID-19 pandemic. J Am Geriatr Soc. 2021;69:320-2.

7. Fallon A, Dukelow T, Kennelly SP, O'Neill D. COVID-19 in nursing homes. QJM 2020;113:391-2.

8. Tan LF, Seetharaman SK. COVID-19 outbreak in nursing homes in Singapore. J Microbiol Immunol Infect. 2021;54:123-4.

9. McMichael TM, Currie DW, Clark S, Pogosjans S, Kay M, Schwartz NG et al. Epidemiology of covid-19 in a long-term care facility in king county, Washington. New Engl J Med. 2020;382:2005-11.

10. Tseng TG, Wu HL, Ku HC, Tai CJ. The impact of the COVID-19 pandemic on disabled and hospice home care patients. J Gerontol A Biol Sci Med Sci. 2020;75:e128-9.

11. Quigley DD, Dick A, Agarwal M, Jones KM, Mody L, Stone PW. COVID-19 preparedness in nursing homes in the midst of the pandemic. J Am Geriatr Soc. 2020;68:1164-6.

12. Kwlatkowski M, Nadonly TL. At Least 2,300 Nursing Homes Have Coronavirus Cases-and the Reality is Likely Much Worse. Washington, DC: USA Today; 2020

13. Rada AG. Covid-19: the precarious position of Spain's nursing homes. BMJ. 2020;369:m1554.

14. American Geriatrics Society. American geriatrics society policy brief: COVID-19 and nursing homes. J Am Geriatr Soc. 2020;68:908-11.

15. Davidson PM, Szanton SL. Nursing homes and COVID-19: we can and should do better. J Clin Nurs. 2020;29:2758-9.

16. Lloyd-Sherlock PG, Kalache A, McKee M, Derbyshire J, Geffen L, Gomez-Olive Casas F. WHO must prioritise the needs of older people in its response to the covid-19 pandemic. BMJ. 2020;368:m1164.

17. Gaur S, Dumyati G, Nace DA, Jump RL. Unprecedented solutions for extraordinary times: helping long-term care settings deal with the COVID-19 pandemic. Infect Control Hosp Epidemiol. 2020;41:729-30.

18. Anonymous. ECDC Releases COVID-19 Vaccination Rollout Strategies for EU/EEA. European Centre for Disease Prevention and Control. Available from: https://www.ecdc.europa.eu/en/news-events/ecdc-releases-vaccination-rollout-strategies-eueea. [Last accessed on 2021 May 15].

19. Anonymous. COVID-19 Vaccination Strategy in Spain; Update1. Spanish Ministry of Health; 2020. Available from: https://www.mscbs.gob.es/profesionales/saludPublica/ccayes/alertasActual/nCov/vacunaCovid19.htm.

20. Docherty AE, Harrison EM, Green CA, Hardwick HE, Pius R, Norman L, et al. Features of 20133 UK patients in hospital with COVID-19 using the ISARIC WHO clinical characterisation protocol: prospective observational cohort study. BMJ. 2020;369:m1985. 
21. Bernabeu-Wittel $M$, Ternero-Vega JE, Díaz-Jiménez $P$, Conde-Guzmán $C$ Nieto-Martín MD, Moreno-Gaviño L, et al. Death risk stratification in elderly patients with covid-19. A comparative cohort study in nursing homes outbreaks. Arch Gerontol Geriatr. 2020;91:104240.

22. Sengstock DM, Thyagarajan R, Apalara J, Mira A, Chopra T, Kaye KS, et al. Multidrug-resistant Acinetobacter baumannii: an emerging pathogen among older adults in community hospitals and nursing homes. Clin Infect Dis. 2010;50(12):1611-6.

23. McKinnell JA, Singh RD, Miller LG, Kleinman K, Gussin G, He J, et al. The SHIELD orange county project: multidrug-resistant organism prevalence in 21 nursing homes and long-term acute care facilities in Southern California. Clin Infect Dis. 2019;69:1566-73.

24. Inzitari M, Risco E, Cesari M, Buurman BM, Kuluski K, Davey V, et al. Editorial: nursing homes and long term care after COVID-19: a new era? J Nutr Health Aging. 2020;24:1042-6.

25. Anonymous. Scarce, Late, and Bad. The Unacceptable Helplessness of Elderly Citizens Living in Nursing Homes of Spain During COVID-19 (Spanish). Doctors Without Borders (Médicos sin Fronteras); 2020. Available from: https://www.static.msf.es/web/archivos/cov-19/AAFF-MSF-Informe-COVID 19 - Re sidencias - B A J A - N O TA.pdf? ga $=2.163940604 .2100051873 .1600703801-1858459954.1600034663$. [Last accessed on 2021 May 15]

26. Grasselli G, Pesenti A, Cecconi M. Critical care utilization for the CO VID-19 outbreak in Lombardy, Italy: early experience and forecast during an emergency response. JAMA. 2020;323:1545-6.

27. Steinberg E, Balakrishna A, Habboushe J, Shawl A, Lee J. Calculated decisions: COVID-19 calculators during extreme resource-limited situations. Emerg Med Pract. 2020;22:CD1-5.

28. Peterson A, Largent EA, Karlawish J. Ethics of reallocating ventilators in the covid-19 pandemic. BMJ. 2020;369:m1828.

29. Rosenbaum L. Facing covid-19 in Italy-ethics, logistics, and therapeutics on the epidemic's front line. N Engl J Med. 2020;382:1873-5.

30. Mannelli C. Whose life to save? Scarce resources allocation in the COVID-19 outbreak. J Med Ethics. 2020;46:364-6.

31. Warne DJ, Ebert A, Drovandi C, Hu W, Mira A, Mengersen K. Hindsigh is 2020 vision: a characterisation of the global response to the COVID-19 pandemic. BMC Public Health. 2020;20:1868.
32. American Health Care Association. Guidance and Resorts. Available from: https://www.ahcancal.org. [Last accessed on 2021 May 15].

33. John A. Hartford Foundation. COVID-19 Resources for Nursing Homes and Long-term Care. Available from: https://www.johnahartford.org/dissemination-center/view/nursing-home-long-term-care-resources. [Last accessed on 2021 May 15].

34. The Society for Post-acute and Long-term Care Medicine/AMDA. AMDA Update on COVID-19. Available from: https://www.paltc.org/COVID-19. [Last accessed on 2021 May 15].

35. Centers for Disease Control and Prevention. Preparing for COVID-19 in Nursing Homes. Available from: https://www.cdc.gov/coronavirus/2019-ncov/hcp/long-termcare.html. [Last accessed on 2021 May 15].

36. Tay HS, Harwood R. Atypical presentation of COVID-19 in a frail older person. Age Ageing. 2020;49:523-4

37. Ward CF, Figiel GS, McDonald WM. Altered mental status as a novel initial clinical presentation for COVID-19 infection in the elderly. Am J Geriatr Psychiatry. 2020;28:808-11.

38. Borasio GD, Gamondi C, Obrist M, Jox R, For The Covid-Task Force of Palliative Ch. COVID-19: decision making and palliative care. Swiss Med Wkly. 2020;150:w20233

39. Greenfield S, Apolone G, McNeil BJ, Cleary PD. The importance of co-existing disease in the occurrence of postoperative complications and one-year recovery in patients undergoing total hip replacement. Med Care. 1993;31:141-54.

40. Kaplan MH, Feinstein AR. The importance of classifying initial co-morbidity in evaluating the outcome of diabetes mellitus. J Chron Dis. 1973;27:387-404.

41. Lang CC, Mancini DM. Non-cardiac comorbidities in chronic heart failure. Heart. 2007:93:665-71.

42. Bernabeu-Wittel $M$, Ollero-Baturone $M$, Moreno-Gaviño L, Barón-Franco B, Fuertes A, Murcia-Zaragoza J, et al. Development of a new predictive model for polypathological patients. The PROFUND index. Eur J Intern Med. 2011;22:311-7.

43. Lim WS, van der Eerden MM, Laing R, Boersma WG, Karalus N, Town $\mathrm{Gl}$, et al. Defining community acquired pneumonia severity on presentation to hospital: an international derivation and validation study. Thorax. 2003;58:377-82. 